\title{
Erratum to: Ventilator-associated pneumonia in the ICU
}

Atul Ashok Kalanuria', Wendy Ziai $^{2 *}$ and Marek Mirski

After publication of this article [1] it has been found that the name of the second author has been misspelt. The correct name is Wendy Ziai which has been herewith corrected in this erratum.

\section{Author details \\ 'Department of Neurology, University of Maryland School of Medicine, Baltimore, MD 21201, USA. ${ }^{2}$ Department of Anesthesiology/Critical Care Medicine, Johns Hopkins University School of Medicine, Baltimore, MD 21287, USA}

Received: 26 January 2016 Accepted: 26 January 2016

Published online: 28 January 2016

\section{Reference}

1. Kalanuria AA, Ziai W, Mirski M. Ventilator-associated pneumonia in the ICU. Critical Care. 2014;18:208.

\footnotetext{
* Correspondence: weziai@jhmi.edu

Submit your next manuscript to BioMed Central and we will help you at every step:

- We accept pre-submission inquiries

- Our selector tool helps you to find the most relevant journal

- We provide round the clock customer support

- Convenient online submission

- Thorough peer review

- Inclusion in PubMed and all major indexing services

- Maximum visibility for your research

Submit your manuscript at www.biomedcentral.com/submit 